\title{
Does Investing in Marketing Efforts Affect Firm Value and Profitability? An Application with Panel Data Analysis ${ }^{1}$
}

DOI: $10.26466 /$ opus.894186

*

\author{
Mohannad T A Garbiah * - Cüneyd Ebrar Levent** \\ *Master Student, Istanbul Aydin University, Master of Business Administration, Istanbul/Turkey \\ E-Mail: mohannadgarbiah@stu.aydin.edu.tr \\ ORCID: $\underline{0000-0001-7075-6557}$ \\ ** Asst.Prof.Dr., Istanbul Aydin University, Istanbul/Turkey \\ E-Mail: cuneydlevent@aydin.edu.tr \\ ORCID: $\underline{0000-0003-1494-3029}$
}

\begin{abstract}
The purpose of this study is to examine the effect of investing in marketing efforts on profitability and firm value. The scope of the study consists of public companies listed in Borsa Istanbul Services Index (XUHIZ). The study covers 49 companies (196 firm-years) listed in XUHIZ in the period 2016-2019. As dependent variables, the accounting-based performance indicator "ROA" and the market-based performance indicator "Tobin's $Q$ ratio" were used. Investment in marketing efforts was represented by independent variables as marketing intensity and marketing expenses to total operating expenses ratio. In the study, panel data analysis method, which allows both time series and cross-section, was chosen. According to the panel data analysis findings, it was determined that the increase in the ratio of investment in marketing efforts to sales did not have a positive effect on the market value or profitability of the company. On the other hand, it was found that the increase in the ratio of marketing expenses to total operational expenses positively affected both the profitability and the market value of the company. These findings indicate that marketing investments should not be considered separately from other operating expenses of the company, companies that can control other operating expenses and increase the ratio of marketing investments in total expenses can achieve better financial performance.
\end{abstract}

Keywors: Firm Value, Profitability, Marketing, Investment, Financial Performance.

\footnotetext{
${ }^{1}$ This study is derived from Mohannad T A Garbiah's the master's thesis entitled "The Impact of Marketing Efforts on Firm Financial Performance: A Research on Companies in BIST Services Index" under the supervision of Asst.Prof.Dr. Cüneyd Ebrar Levent.
} 


\section{Pazarlama Çabalarına Yatırım Yapmak, Firma Değeri ve Kârlılığını Etkiler mi? Panel Veri Analizi ile Bir Uygulama}

Öz

Bu çalışmanın amacl, pazarlama çabalarına yatırım yapmanın kârlılık ve firma değeri üzerindeki etkisini incelemektir. Çalışmanın kapsamını Borsa İstanbul Hizmetler Endeksinde (XUHIZ) listelenen halka açık şirketler oluşturmaktadır. Çalışma, 2016-2019 arasındaki dönemde XUHIZ'de listelenen 49 şirketi (196 firma-yıl) kapsamaktadır. Bağımlı değişkenler olarak, muhasebe temelli performans göstergesi olan "ROA" ve piyasa temelli performans göstergesi olan "Tobin's $Q$ oranı" kullanılmıştır. Pazarlama çabalarına yapılan yatırım, pazarlama yoğunluğu ve pazarlama giderlerinin toplam faaliyet giderlerine oran bağımsı değişkenleriyle temsil edilmiştir. Çalışmada hem zaman serilerine hem de kesitlere izin veren panel veri analizi yöntemi kullanılmıştır. Araştırma bulgularına göre, pazarlama çabalarına yatırımın satışlara oranındaki artışın şirketin piyasa değeri veya kârlılı̆̆ üzerinde olumlu bir etkiye sahip olmadı̆̆ tespit edilmiştir. Öte yandan pazarlama giderlerinin toplam faaliyet giderlerine oranındaki artışın şirketin hem kârlılı̆̆ını hem de piyasa değerini olumlu etkilediği saptanmıştır. Bu bulgular, pazarlama yatırımlarının şirketin diğer faaliyet giderlerinden ayrn düşünülmemesi gerektiğini, diğer faaliyet giderlerini kontrol edebilen ve pazarlama yatırmlarını toplam giderler içindeki payını artıran şirketlerin daha iyi finansal performans elde edebileceğini göstermektedir.

AnahtarKelimeler: Firma Değeri, Kârlılık, Pazarlama, Yatırım, Finansal Performans. 


\section{Introduction}

As a result of the increasing competition and globalization, finance has been at the forefront among the basic functions of the business. In addition, it is the determinant of "maximizing firm value", which is accepted as the main purpose of the business. The hegemony of finance over other business activities almost as a single function (Bolton, 2004) has resulted in the association of everything with finance or financial performance. This puts more and more pressure on practitioners to report their contribution to overall firm (financial) performance (Kundu, Kulkarni, and Murthy, 2010).

Marketing, another basic function of the business, is within the group that feels this pressure of finance (and financial performance) most intensely. This pressure is a problem in businesses where marketing and finance work disconnected from each other. In businesses where coordination and cooperation between departments exist, finance and marketing are complementary elements and they act in line with the business objectives. From a financial perspective, shareholders form the central stakeholder group and efforts focuses on the creation of shareholder value; from a marketing perspective, consumers represent the main constituency, and the focus is based on attitudes and behaviors driving revenues in the market (Madden, Fehle, and Fournier, 2006). These two approaches serve to increase the value of the firm.

Having an effective marketing management in the firm supports the increase of both profitability and firm value; Kotler (1997) emphasizes the importance of analyzing, planning, implementing, and monitoring programs designed to achieve the organizational targets of the desired changes with target markets in marketing management. All these factors are related to "customer equity", this equity is related to the added value created and the benefit to the firm, naturally, financial parameters are frequently used in measuring benefit (Sheth and Sisodia, 2002). From this point of view, whether it is referred to as customer value or firm value, to achieve this value, a firm have to spend financial effort that cannot be limited by the famous 4 P's of Marketing, and allocate a budget for marketing investment. 
In the traditional approach, the concept of investment is generally associated with investments made in tangible fixed assets, and investments such as land, buildings, machinery, and equipment in production enterprises are considered as factors that increase the amount of the company's products in the long term and enable the company to grow. In this respect, service businesses - which are relatively less fixed asset investments - are incorrectly classified as businesses that generate profits with low investment. However, it has become an indisputable fact that companies (regardless of the sector) should invest not only in productionrelated elements, but also in efforts to increase sales, with the right strategies, in today's world where competition has increased excessively. Since the importance of sales in commercial survival and the connection between customers and sales is clearer, it is appropriate for organizations to focus on the factors that may affect the consumers' decision to purchase their products (Agbeja, Adelakun, and Akinyemi, 2015). In this respect, marketing expenses can be considered as investments that create value and increase market value (Öztürk and Dülgeroğlu, 2016).

On the other hand, marketing and advertising expenses are accepted as a negative factor to influence the profitability in the short term (Topuz and Akşit, 2013; Doğan and Mecek, 2015; Konak, 2015). However, marketing has long been regarded as investment rather than expense in the long term to add value for the firms (Sheth and Sisodia, 2002; Slywotzky and Shapiro, 1993).

In this context, this study aims to determine whether the investments of companies in their marketing efforts have an effect on the firm value and profitability. The scope of the study consists of public companies listed in Borsa Istanbul Services Index (XUHIZ). The most important reason for selecting firms in this index is since it is believed that firms in the services sector may be more sensitive to marketing investments than other sectors. This study also aims to determine empirically whether this belief is valid for Turkey.

The study covers 66 firms traded on the XUHIZ between 2016-2019. The final data set of the research consists of 49 companies, covering the 4-years period (196 firm-years). In the study, panel data analysis method, which allows both time series and cross-section, is used. The research has two dependent variables analyzed in separate models, one of which 
is firm value and the other is profitability represented by Return on Assets (ROA). The main independent variable of the study is investments in marketing efforts. Marketing intensity and the ratio of marketing expenses to operating expenses are used as representatives of this.

This study differs from the studies in the literature by considering it as marketing effort and investment, in contrast to the accounting approach that sees marketing expenditures as a factor that reduces income. Another importance of the study is that it covers the service sector. In studies examining the impact of marketing expenses, it has been observed that the service sector is not sufficiently examined. With these aspects, the study aims to fill this gap in the literature.

In the following section of this study, a literature review regarding the financial performance of marketing investments is included. The next section explains the data and methodology of the research. Descriptive statistics, correlation analysis, unit root test, multicollinearity test, Honda and Hausman tests and finally panel data regression results are included in the findings section. Final section will interpret the results and concludes the whole research.

\section{Literature Review}

Research in the literature reveals that awareness of the need to measure the impact of marketing efforts on firm performance is growing. Studies investigating the impact of marketing efforts on the financial performance of the firm mostly include Tobin's Q, Return on Assets, Return on Equity as financial indicators representing performance. In this section, various studies in the literature on this subject are examined.

Qureshi (2007) investigated the relationship between marketing expenditures and market performance in a study carried out over companies operating in England between 1998 and 2003. Following the research using the least squares method, the author found that marketing expenses and market performance are related in a positive and statistically significant way.

Al-Nimer, Qasem, Aladham, and Yousef (2015) studied the impact on the profitability of companies of advertising and marketing expenses, and determined how advertising and marketing expenses are used to 
boost companies' profitability. Data from their study were collected from the annual audited reports between 2009 and 2013 of 68 Jordanian medical companies. Advertising and marketing expenses were used as independent variables and companies' profitability as dependent variable. In order to evaluate the effect of the independent variable on the dependent variable, simple regression model was used to detect the relationship between advertising and marketing expenses and profitability of the firm. As a result of the study, they concluded that there was an impact between advertising and marketing expenses and net profit on medical companies on the Amman Stock Exchange. Similarly, Gupta (2008) examined the impact of marketing expenditures (represented by advertising expenditures) on firm performance over the firms operating in the textile, automotive and food industries in India based on the data between 1997-2006. The author found a positive relationship between marketing expenses and profitability for the automotive industry in the study; on the other hand, a negative relationship between marketing expenses and profitability for the textile and food sector.

Konak's (2015) study examines the effect of marketing, distribution and sales expenses on the market value of companies and whether there is a significant relationship between them. Data of his study were collected from the audited annual reports of the 22 companies listed in the BIST Textile, Leather Index between 2009-2013. In the research, the author used "changes in marketing expenditures" over an interval of time as independent variable and "Tobin's Q", "Return on Assets (ROA)" and "Return on Equity (ROE)" as indicators for firm performance, and " Size of Sales" and "Leverage Ratio" as control variables. Cross sectional time series analysis technique and pooled OLS method were used to detect the relationship between marketing expenses and the market value and profitability of the firm. As a result of the study, he found that there was a positive and statistically significant relationship between change in marketing expenditures and firm performance when ROA and ROE were considered an indicator of firm profitability. But when "Tobin's Q" was used as an indicator of market value, a negative relationship was found for firm performance but not statistically significant.

Doğan and Mecek's (2015) study investigated the impact of marketing expenditures on firm performance, and whether there was a significant 
relationship between them. Data of the study were collected from the audited annual reports of the 120 companies, which were listed on Borsa Istanbul (BIST) between 2009-2012. In the research, the authors used "concentration of marketing spending" which is the marketing expenditures to total sales ratio as independent variables, and Tobin's $Q$ ratio, ROA and ROE as dependent variables. Multiple regression and correlation methods were used to evaluate the effect of independent variables on dependent variables, that is, to determine the relationship between marketing expenses and firm performance. The authors found that there was a positive relationship between marketing expenses with the accounting based (ROA and ROE) and market-based performance indicators (Tobin's Q). This means that both firm profitability and firm value increase when invested in marketing efforts.

Kundu et al. (2010) aimed to reveal the relationship between marketing, finance and strategy. In the study, the authors analyzed the effect of marketing expenditures (represented by advertising expenditures) on the profitability and value of the firm and whether there is a significant relationship between them. The study was conducted on companies operating in India. Data were collected from 172 companies between 20002007. In the research, the authors used "marketing expenditures" as an independent variable, and "Tobin's Q" and "profitability" as dependent variables. Multiple regression, ANOVA and correlation methods were used. As a result of the study, a statistically insignificant link between marketing expenditures and Tobin's $Q$ and profitability was found.

Han and Manry (2004) examined the value of "Research and Development" (R\&D) and advertising expenses of Korean firms. The study was conducted on companies operating in Korea. Data of the study were collected from 625 companies listed on the Korean Stock Exchange between 2012 and 2016. By using regression model tests to analyze the data, they found RandD expenditures are, in general, positively associated with stock price. But advertising expenditures were found to be negatively associated with stock price.

Whether the investments in marketing expenses have a financial benefit or not is considered to vary by sector. For example, in the tourism sector, marketing expenditures are expected to have a net contribution to companies. In this context, the relationship between marketing expenses 
and profitability in the tourism sector has been investigated by Serçek, Kaya, and Kalash (2018). The authors tried to reveal the relationship between marketing expenses and profitability by using the data of 20122015 of 10 tourism companies whose stocks are traded in Borsa Istanbul (BIST). The authors found that the relationship between marketing expenses and profitability was statistically insignificant.

\section{Research Methodology}

\section{Data Collection Method}

The purpose of this research is to examine the effect of investing in marketing efforts on the profitability and firm value. The study covers 66 firms traded on the Borsa Istanbul Services Index (XUHIZ) between 2016-2019. Data were collected from audited annual reports published on the Public Disclosure Platform (Kamuyu Aydinlatma Platformu: KAP). Since the data used in the study are open to the use of all investors, stakeholders and researchers, there is no need for an ethics report.

The initial sample started with 66 firms in the XUHIZ index. 6 firms with different accounting periods (four of them are sports clubs) and 3 firms with zero sales in some years were eliminated. 8 firms were excluded from the research because they were listed on BIST after 2016. The total number of the sample is 196 firm years for 49 listed firms during 2016-2019.

\section{Research Variables}

There are various alternative measures of financial performance, such as Return on Assets (ROA) and Tobin's Q. Tobin's Q ratio is widely utilized as a proxy for future investment opportunities in financial literature, the $\mathrm{Q}$ ratio is a market value of a company divided by the cost for replacement of assets of a company (Fu, Singhal, and Parkash, 2016). Tobin's $Q$ is a good measure for evaluating business performance in line with the past, current, and future performance of the company. It widely used by most researchers to measure the firm value. In addition, ROA indicates how profitably a company is compared to its total assets. ROA gives a 
manager, investor, or analyst an idea of how efficiently a company's management can generate profit through its assets (Mcclure, 2020), therefore ROA and Tobin's $Q$ are taken as the indicator to measure the financial performance for firms.

The main independent variable of the study is "investment in marketing efforts". In this study, marketing intensity and the ratio of marketing expenses to total operating expenses were used as independent variables representing investment in marketing efforts. Additionally, the natural logarithm of total assets (LNSIZE) and debt ratio (DEBT) are used as control variables in econometric models.

Table 1 shows the dependent, independent and control variables used in the study. In particular, the following dependent variables have been chosen as indicators of firm performance.

Table 1. Descriptions of Variables Used in Analysis

\begin{tabular}{|c|c|c|}
\hline \multicolumn{3}{|c|}{ Dependent Variables (Tobin's Q, ROA) } \\
\hline Variables & Definition & Measurement \\
\hline Tobin's Q & $\begin{array}{l}\text { Tobin's Q ratio } \\
\text { (Firm value) }\end{array}$ & $\begin{array}{l}\text { (Total Debt + Market Capitaliza- } \\
\text { tion)/Total Assets }\end{array}$ \\
\hline ROA & $\begin{array}{l}\text { Return on Assets } \\
\text { (Profitability) }\end{array}$ & Net Profit /Total Assets \\
\hline \multicolumn{3}{|c|}{ Independent Variables (MTS, MTOE) } \\
\hline Variables & Definition & Measurement \\
\hline MTS & Marketing Intensity & $\begin{array}{l}\text { Marketing, Sales and Distribution } \\
\text { Expenses/Total Sales }\end{array}$ \\
\hline MTOE & $\begin{array}{l}\text { Marketing Expense-To-Total } \\
\text { Operating Expenses }\end{array}$ & $\begin{array}{l}\text { Marketing, Sales and Distribution } \\
\text { Expenses/Total Operating Expenses }\end{array}$ \\
\hline \multicolumn{3}{|c|}{ Control Variables (LNSIZE, DEBT) } \\
\hline Variables & Definition & Measurement \\
\hline LNSIZE & Firm size & Natural Logarithm of Total Assets \\
\hline DEBT & Debt Ratio & Total Debts/ Total Assets \\
\hline
\end{tabular}

\section{Quantitative / Qualitative Analysis}

Due to the time and horizontal cross-sectional dimensions of the research, the panel data analysis method was preferred. In this research, STATA 14 and EVIEWS 9 programs were used for panel data analysis. 


\section{Research Models}

As mentioned above, panel data analysis was used that considers both time and cross-sectional dimensions to determine the relationship between investment in marketing efforts and firm performance (profitability and firm value). In this context, the econometric models developed for research are:

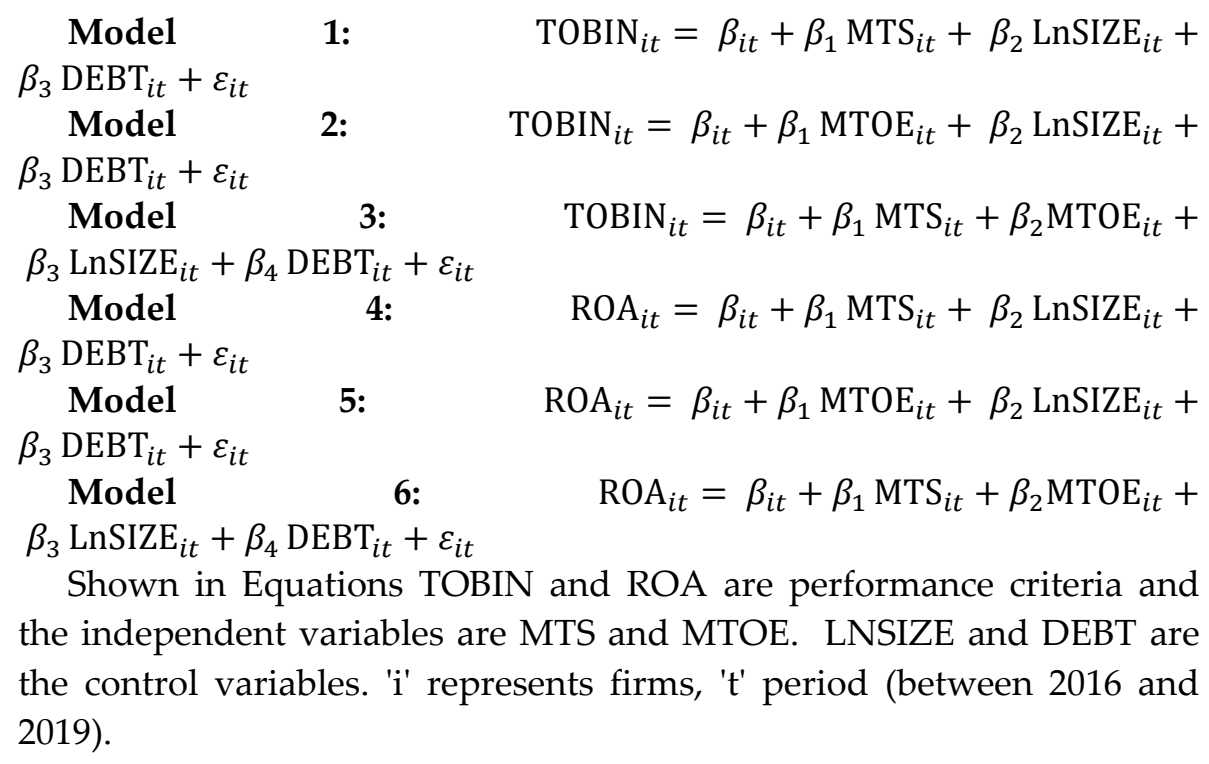

\section{Research Findings}

Descriptive statistical results of dependent and independent variables used in empirical analysis are shown in Table 2. The TOBIN variable takes the lowest 0.4682 , the highest 12.6035 , and has an average value of 1.4095. The Return on Assets (ROA) variable, which represent the firm profitability takes the lowest -0.2656 , the highest 0.5239 , and has an average value of 0.0453 . A negative ROA implies that some companies cannot effectively use its assets to generate profit. The MTS, which is the first variable representing the marketing intensity, used to determine the cost of marketing activities to generate sales levels in each period, and this variable, takes the lowest 0 , the highest 0.4393 . The second variable 
(MTOE), which shows the ratio of marketing expenses to operating expenses, and this variable takes the lowest 0 , the highest 0.8717 and has an average value of 0.2454 . Firm size is represented by the natural logarithm of firms' total assets. This variable is distributed between 16.2065 and 25.7128. The last variable in descriptive statistics is DEBT ratio, which measures the leverage of a company with an average value of 0.6180 .

Table 2. Descriptive Statistics

\begin{tabular}{lllllll}
\hline & Mean & Median & Maximum & Minimum & Std. Dev. & Obs. \\
\hline TOBIN & 1.4095 & 1.1573 & 12.6035 & 0.4682 & 1.1114 & 196 \\
ROA & 0.0453 & 0.0401 & 0.5239 & -0.2656 & 0.0936 & 196 \\
MTS & 0.0519 & 0.0127 & 0.4393 & 0.0000 & 0.0821 & 196 \\
MTOE & 0.2454 & 0.1139 & 0.8717 & 0.0000 & 0.2867 & 196 \\
LNSIZE & 20.4358 & 20.2341 & 25.7128 & 16.2065 & 2.1150 & 196 \\
DEBT & 0.6180 & 0.6518 & 1.1665 & 0.0086 & 0.2603 & 196 \\
\hline
\end{tabular}

The correlation matrix of the variables included in the study is presented in Table 3. It is seen here that there is a very high correlation (0.7551) between MTS and MTOE variables representing the marketing efforts. This may cause multicollinearity problem. MTS and MTOE were analyzed separately in four models but together in two models. Therefore, Variance Inflation Factor (VIF) tests were applied for the existence of multicollinearity problem in models where MTS and MTOE are examined together, the results given in Table 4 will be interpreted in detail later.

Table 3. Correlation Matrix

\begin{tabular}{lllllll}
\hline & TOBIN & ROA & MTS & MTOE & LNSIZE & DEBT \\
\hline TOBIN & 1 & & & & & \\
ROA & 0.1320 & 1 & & & & \\
MTS & 0.0070 & -0.0883 & 1 & & & \\
MTOE & 0.1346 & 0.0482 & 0.7551 & 1 & & \\
LNSIZE & -0.1939 & 0.1729 & 0.1683 & 0.4150 & 1 & \\
DEBT & -0.0854 & -0.0798 & 0.2097 & 0.3155 & 0.3796 & 1 \\
\hline
\end{tabular}

As seen in Table 3, positive results were obtained between MTS and TOBIN, between MTOE and TOBIN and between MTOE and ROA. In other words, as the MTS and MTOE increase, the ratio of Tobin's Q also increases. Another prominent point in the correlation matrix is the presence of an inverse relationship between MTS and ROA. Whether these 
relationships are significant or not can only be said after the panel data analysis results, which consider the cross-section and time dimensions of the series.

As stated above, the high correlation between MTS and MTOE may indicate the possibility of multicollinearity problem in all models. Therefore, Variance Inflation Factor (VIF) tests were applied to the models to ensure that there was no multicollinearity problem (Table 4 ).

Table 4. Variance Inflation Factor (VIF) tests

\begin{tabular}{llll}
\hline Model 1and4 & & & \\
Variable & Coefficient Variance & VIF & Result \\
\hline MTS & 0.967676 & 1.0562 & VIF $<5$ \\
LNSIZE & 0.001629 & 1.1797 & VIF $<5$ \\
DEBT & 0.109304 & 1.1990 & VIF $<5$ \\
C & 0.598953 & - & \\
Model 2and5 & & & \\
Variable & Coefficient Variance & VIF & \\
MTOE & 0.088537 & 1.2522 & VIF $<5$ \\
LNSIZE & 0.001711 & 1.3173 & VIF $<5$ \\
DEBT & 0.103813 & 1.2110 & VIF $<5$ \\
C & 0.621364 & - & \\
Model 3and6 & & & \\
Variable & Coefficient Variance & VIF & \\
MTS & 2.032229 & 2.4745 & VIF $<5$ \\
MTOE & 0.197729 & 2.9337 & VIF $<5$ \\
LNSIZE & 0.001731 & 1.3982 & VIF $<5$ \\
DEBT & 0.099024 & 1.2118 & VIF $<5$ \\
C & 0.628636 & - & \\
\hline
\end{tabular}

According to Menard (2001), VIF values less than 5 are acceptable. When the results in Table 4 were examined, no inconsistency was found in all models. When the results in Table 4 were examined, no inconsistency was found in all models. In the econometric models established; It should be emphasized again that Model 1 and Model 4; Model 2 and Model 5; Model 3 and Model 6 contain the same independent variables.

In time series analysis, unreal relationships may arise in regressions with non-stationary series, causing misleading results. Stationarity is an assumption that has to be fulfilled before regression analysis for panel data analyses, where the cross-sectional aspect is included in the time dimension. In the econometrics literature, various unit root tests have been developed to determine the stationaries of panel series data. The stationarity test developed by Levin, Lin, and Chu (2002), one of the sec- 
ond-generation unit root tests, was chosen for this study. The results of the Levin, Lin, and Chu (LLC) unit root test presented in Table 5 show that in a series of variables there is no unit root in all models, so that stationarity assumption is achieved.

Table 5. Unit Root Test Results

\begin{tabular}{llll}
\hline Variables & Statistics Value & Probability Value $(\mathrm{p})$ & Result \\
\hline TOBIN & -8.69556 & $0.0000^{* * * *}$ & No unit root \\
ROA & -9.66525 & $0.0000^{* * *}$ & No unit root \\
MTS & -14.7608 & $0.0000^{* * *}$ & No unit root \\
MTOE & -20.7617 & $0.0000^{* * *}$ & No unit root \\
LNSIZE & -28.9416 & $0.0000^{* * *}$ & No unit root \\
DEBT & -14.573 & $0.0000^{* * *}$ & No unit root
\end{tabular}

Levin, Lin, Chu unit root test was applied.

$*, * * * * *$ means statistical significance at $10 \%, 5 \%$ and $1 \%$ levels.

The next step is to choose the appropriate panel data method. In this context, various tests are performed on panel data models to determine whether the models can be pooled (poolibility) or whether fixed or random effects models are appropriate. First, the suitability of the models with the pool model is examined with the Honda (1985) test. The Honda test is more advanced than the Breusch and Pagan (1980) test, but both tests yield important results regarding the poolability of the models. Acceptance of $\mathrm{H}_{0}$ hypothesis in the Honda test application means that random effects do not occur (Baltagi, Song, and Koh, 2003), therefore the data cannot be pooled, and a random effect will occur if rejected. The test results in Table 6 show that the Honda test null hypothesis is rejected $(\mathrm{P}<0.05)$, and random effects can be found in every single model.

Table 6. Honda Test Results

\begin{tabular}{llll}
\hline & Statistics Value & Probability Value $(\mathrm{p})$ & Result \\
\hline $\begin{array}{l}\text { Model 1 } \\
\text { Cross-section }\end{array}$ & 5.1654 & $0.0000^{* * *}$ & \\
Time & -0.2326 & - & Model cannot be pooled \\
Both & 3.4880 & $0.0002^{* * *}$ & Model cannot be pooled \\
\hline Model 2 & & & Model cannot be pooled \\
Cross-section & 4.4868 & $0.0000^{* * *}$ & Model cannot be pooled \\
Time & -0.1396 & -- & Model cannot be pooled \\
Both & 3.0739 & $0.0011^{* * *}$ & Model cannot be pooled \\
\hline $\begin{array}{l}\text { Model 3 } \\
\text { Cross-section }\end{array}$ & 3.7949 & & \\
Time & -0.2326 & $0.0001^{* * *}$ & Model cannot be pooled \\
& & -- & Model cannot be pooled
\end{tabular}




\begin{tabular}{llll} 
Both & 2.4145 & $0.0079^{* * *}$ & Model cannot be pooled \\
\hline Model 4 & & & \\
Cross-section & 7.0344 & $0.0000^{* * *}$ & $\begin{array}{l}\text { Model cannot be pooled } \\
\text { Time }\end{array}$ \\
Both & -0.9866 & $--0000^{* * *}$ & Model cannot be pooled \\
\hline Model 5 & 4.2765 & $0.0000^{* * *}$ & Model cannot be pooled \\
Cross-section & 6.9075 & -- & Model cannot be pooled \\
Time & -0.9741 & $0.0000^{* * *}$ & Model cannot be pooled \\
Both & 4.1956 & $0.0000^{* * *}$ & Model cannot be pooled \\
\hline Model 6 & & -- & \\
Cross-section & 7.0570 & $0.0000^{* * *}$ & Model cannot be pooled \\
Time & -0.8805 & Model cannot be pooled \\
Both & 4.3675 &
\end{tabular}

The next step is to investigate whether models are suitable for fixed effects or for model random effects after it has been determined that the panel data models cannot be pooled. The Hausman (1978) test is used for this purpose. The Hausman test shows that acceptance of the null hypothesis $\left(\mathrm{H}_{0}\right)$ indicates the suitability of the random effects model and its rejection indicates that the fixed effects model should be applied. According to Hausman test results in Table $7, \mathrm{H}_{0}$ hypotheses were approved $(\mathrm{P}>0.05)$ and it was decided to use random effects method in all models.

Table 7. Hausman Test Results

\begin{tabular}{llll}
\hline Model 1 & Statistics Value & Probability Value (p) & Result \\
\hline Model 2 & 2.2193 & 0.5282 & $\begin{array}{l}\text { Random effects method } \\
\text { should be chosen }\end{array}$ \\
\hline Model 3 & 2.1368 & 0.5445 & $\begin{array}{l}\text { Random effects method } \\
\text { should be chosen }\end{array}$ \\
\hline Model 4 & 3.2516 & 0.5166 & $\begin{array}{l}\text { Random effects method } \\
\text { should be chosen }\end{array}$ \\
\hline Model 5 & 7.6188 & $0.0546^{*}$ & $\begin{array}{l}\text { Random effects method } \\
\text { should be chosen }\end{array}$ \\
\hline Model 6 & 5.6121 & 0.1321 & $\begin{array}{l}\text { Random effects method } \\
\text { should be chosen }\end{array}$ \\
\hline
\end{tabular}

$*, * *, * *$ means statistical significance at $10 \%, 5 \%$ and $1 \%$ levels.

The following tables present the results of the panel regression test based on random effects model. Robust estimators were used to estimate models. In the case of heteroscedasticity and/or autocorrelation, robust 
estimators were used to generate a prediction detected in regression models. In this regard, estimates in the following tables have been based on the Tatoğlu (2016) recommended clustered robust standard error method.

According to the results given in Model 1, the Wald $\operatorname{chi}^{2}(3)$ value was calculated as 6.84 (Table 8 ). Wald chi probability value $\mathrm{P}$ was determined as 0.0773 . It is seen that the variables in the model can explain the firm value $\left(\right.$ TOBIN) by $3.82 \%\left(R^{2}=0.0382\right)$. When Model 1 was examined, it was found that there is no relationship between marketing intensity (MTS) and firm value (TOBIN) $(\mathrm{z}=0.47, \mathrm{P}=0.639>0.005)$. Firm size (LNSIZE), which is included as a control variable in the study, has a negative effect on firm value (TOBIN). This effect is statistically significant ( $\mathrm{z}$ $=-2.22, \mathrm{P}=0.027)$. It was found that the other control variable, debt ratio (DEBT), did not have a statistically significant relationship with TOBIN. $(\mathrm{P}=0.826>0.05)$.

Table 8. Model 1 Panel Regression Test Results

\begin{tabular}{lllll}
\hline \multicolumn{1}{l}{ Dependent Variable: TOBIN } & Coefficient & Robust Std. Error & $\mathrm{z}$ statistics & Probability Value (p) \\
\hline MTS & 0.3750365 & 0.7989334 & 0.47 & 0.639 \\
LNSIZE & -0.1153634 & 0.0520062 & -2.22 & $0.027^{* *}$ \\
DEBT & 0.0769689 & 0.3507153 & 0.22 & 0.826 \\
C & 3.700027 & 1.130133 & 3.27 & $0.001^{* * *}$ \\
\hline
\end{tabular}

$N$ (number of observations): 196, Wald chi $^{2}(3): 6.84$ (Probability value: 0.0773 ), $R^{2}$ :

$*, * * * * *$ means statistical significance at $10 \%, 5 \%$ and $1 \%$ levels.

In Model 2, the dependent variable is TOBIN as in the first model. However, in this model, the variable of MTOE is included as an independent variable instead of MTS. According to the results given in Table 9, the model is meaningful (Wald $\operatorname{chi}^{2}(3)$ value 9.09, Wald chi probability value $=0.0281$ ). Explanation power of the model is $R^{2}=9.55 \%$. The $z-$ statistic value of the MTOE variable expressing the marketing expenditures in relation to operating expenditures is 2.09 and has a significant and positive relationship with TOBIN $(P=0.037<0.05)$. LNSIZE variable has a negative effect on TOBIN. This effect is statistically significant $(\mathrm{z}=-$ $2.89, \mathrm{P}=0.004)$. The other control variable, debt ratio (DEBT), was found 
to not have a statistically significant relationship with TOBIN ( $\mathrm{P}=0.763$ $>0.05$ ).

Table 9. Model 2 Panel Regression Test Results

\begin{tabular}{lllll}
\hline Dependent Variable: TOBIN & Coefficient & Robust Std. Error & z statistics & Probability Value (p) \\
\hline MTOE & 1.030872 & 0.4929967 & 2.09 & $0.037^{* *}$ \\
LNSIZE & -0.1594106 & 0.0551021 & -2.89 & $0.004^{* * *}$ \\
DEBT & -0.1011521 & 0.3348617 & -0.3 & 0.763 \\
C & 4.47667 & 1.175609 & 3.81 & $0.000^{* * *}$ \\
\hline
\end{tabular}

$N$ (number of observations): 196, Wald chi'(3): 9.09 (Probability value: 0.0281), $R^{2}: 0.0955$ $*, * * * * *$ means statistical significance at $10 \%, 5 \%$ and $1 \%$ levels.

In Model 3, the dependent variable is TOBIN as in the first and second model. However, in this model, the variables of MTS and MTOE are included together as independent variables. According to the results given in Table 10, the model is completely meaningful (Wald chi²(4) value 11.14, Wald chi probability value 0.0250). Explanation power of the model is $\mathrm{R}^{2}=14.17 \%$. MTS variable negatively affects the dependent variable TOBIN at the $10 \%$ significance level $(z=-1.81, P=0.070)$. The $z-$ statistic value of the MTOE variable is 2.19 and has a significant and positive relationship with TOBIN $(\mathrm{P}=0.029<0.05)$. LNSIZE variable has a negative effect on TOBIN. This effect is statistically significant $(z=-3.03$, $P=0.002$ ). The other control variable, debt ratio (DEBT), was also found to not have a statistically significant relationship with TOBIN $(\mathrm{P}=0.802>0.05)$

Table 10. Model 3 Panel Regression Test Results

\begin{tabular}{lllll}
\hline Dependent Variable: TOBIN & Coefficient & Robust Std. Error & z statistics & Probability Value (p) \\
\hline MTS & -4.043575 & 2.23216 & -1.81 & $0.070^{*}$ \\
MTOE & 1.999089 & 0.9144559 & 2.19 & $0.029^{* * *}$ \\
LNSIZE & -0.1874535 & 0.0618127 & -3.03 & $0.002^{* * *}$ \\
DEBT & -0.0860548 & 0.3436554 & -0.25 & 0.802 \\
C & 5.012468 & 1.282602 & 3.91 & $0.000^{* * *}$ \\
\hline
\end{tabular}

$N$ (number of observations): 196, Wald chi' ${ }^{2}(4): 11.14$ (Probability value: 0.0250), $R^{2}: 0.1417$ $*, * * * * *$ means statistical significance at $10 \%, 5 \%$ and $1 \%$ levels.

In Model 4, the dependent variable is Return on Assets (ROA). According to the results given in Table 11, the Wald $\operatorname{chi}^{2}(3)$ value is 14.2 and 
Wald chi probability value is 0.0027 . Explanation power of the model is $\mathrm{R}^{2}=5.91 \%$. When Model 4 was examined, it was found that there is no relationship between marketing intensity (MTS) and firm profitability (ROA) $(z=-1.61, P=0.107>0.05)$. In other words, the marketing expenses of the companies do not contribute to the increase in profitability of the firms. In this model, it was found that the firm size (LNSIZE) has a positive effect on firm profitability (ROA). This effect is statistically significant $(\mathrm{z}=2.83, \mathrm{P}=0.005)$. The other control variable, DEBT was found, negatively affects the dependent variable ROA at the $10 \%$ significance level $(\mathrm{z}=-1.68, \mathrm{P}=0.093)$.

Table 11. Model 4 Panel Regression Test Results

\begin{tabular}{lllll}
\hline Dependent Variable: ROA & & & \\
\hline & Coefficient & Robust Std. Error & z statistics & Probability Value (p) \\
\hline MTS & -0.2150495 & 0.1334376 & -1.61 & 0.107 \\
LNSIZE & 0.0129287 & 0.0045724 & 2.83 & $0.005^{* * *}$ \\
DEBT & -0.0870619 & 0.0517525 & -1.68 & $0.093^{*}$ \\
C & -0.153907 & 0.1068057 & -1.44 & 0.150 \\
\hline
\end{tabular}

$N$ (number of observations): 196, Wald chi ${ }^{2}(3): 14.2$ (Probability value: 0.0027$), R^{2}: 0.0591$ $*, * *, * *$ means statistical significance at $10 \%, 5 \%$ and $1 \%$ levels.

In Model 5, the dependent variable is ROA as in the fourth model. However, in this model, the variable of MTOE is included as an independent variable instead of MTS. According to the results given in Table 12 , the Wald $\operatorname{chi}^{2}(3)$ value is 12.62 and the Wald chi ${ }^{2}$ probability value is 0.0055 . Explanation power of the model is $\mathrm{R}^{2}=5.11 \%$. When Model 5 was examined, it was found that there is no relationship between MTOE and ROA $(z=-0.29, P=0.774>0.05)$. LNSIZE variable has a positive effect on ROA. This effect is statistically significant $(z=2.57, P=0.010)$. The other control variable, debt ratio (DEBT) was found, negatively affects the dependent variable $\mathrm{ROA}$ at the $10 \%$ significance level $(\mathrm{z}=-1.76, \mathrm{P}=0.078)$.

Table 12. Model 5 Panel Regression Test Results

\begin{tabular}{lllll}
\hline Dependent Variable: ROA & \multicolumn{3}{l}{} \\
\hline & Coefficient & Robust Std. Error & z statistics & Probability Value (p) \\
\hline MTOE & -0.0114717 & 0.0399528 & -0.29 & 0.774 \\
\hline LNSIZE & 0.0126756 & 0.0049272 & 2.57 & $0.010^{* *}$ \\
\hline DEBT & -0.0945179 & 0.0536758 & -1.76 & $0.078^{*}$ \\
\hline C & -0.1524631 & 0.1133855 & -1.34 & 0.179 \\
\hline
\end{tabular}


$N$ (number of observations): 196, Wald chi2(3): 12.62 (Probability value: 0.0055$), R^{2}: 0.0511$ $*, * * * *$ means statistical significance at $10 \%, 5 \%$ and $1 \%$ levels.

In Model 6, the dependent variable is ROA as in the fourth and fifth model. However, in this model, the variables of MTS and MTOE are included together as independent variables. According to the results given in Table 13, the Wald $\operatorname{chi}^{2}(4)$ value is 14.8 and Wald chi probability value is 0.0051 . Explanation power of the model is $\mathrm{R}^{2}=7.39 \%$. The MTS variable has a significant and negative relationship with ROA $(z=-2.29$, $\mathrm{P}=0.022)$. The MTOE variable, positively affects the dependent variable $\mathrm{ROA}$ at the $10 \%$ significance level $(\mathrm{z}=1.7, \mathrm{P}=0.088)$. LNSIZE variable also has a positive effect on ROA. This effect is statistically significant ( $\mathrm{z}$ $=1.98, \mathrm{P}=0.048)$. The other control variable, debt ratio (DEBT) was found, negatively affects the dependent variable ROA at the $10 \%$ significance level $(z=-1.75, P=0.081)$.

Table 13. Model 6 Panel Regression Test Results

\begin{tabular}{lllll}
\hline Dependent Variable: ROA & & & \\
\hline & Coefficient & Robust Std. Error & z statistics & Probability Value (p) \\
\hline MTS & -0.379468 & 0.1660619 & -2.29 & $0.022^{* *}$ \\
MTOE & 0.0796552 & 0.0467431 & 1.70 & $0.088^{*}$ \\
LNSIZE & 0.0098585 & 0.004982 & 1.98 & $0.048^{* *}$ \\
DEBT & -0.0907655 & 0.051981 & -1.75 & $0.081^{*}$ \\
C & -0.0999004 & 01169485 & -0.85 & 0.393 \\
\hline
\end{tabular}

$N$ (number of observations): 196, Wald chi ${ }^{2}(4): 14.80$ (Probability value: 0.0051$), R^{2}: 0.0739$ $*, * *, * *$ means statistical significance at $10 \%, 5 \%$ and $1 \%$ levels.

As discussed above, in any of the models established in this research, there is no evidence that increasing the ratio of marketing, sales and distribution expenses to sales will increase the market value of the firm. This is not surprising, because it is not possible for investors to be rewarded in the market for investments related to the company, except for "institutional investors". What is interesting is that the MTS variable does not have a positive effect on profitability.

On the other hand, the increase in the ratio of Marketing Expense-ToTotal Operating Expenses (MTOE) positively affects both the profitability and the market value of the company. Especially the findings ob- 
tained in Model 3 and Model 6, in which MTS and MTOE take place together, strongly support this result.

\section{Conclusion}

The purpose of this study is to examine the effect of investing in marketing efforts on the profitability and firm value. The scope of the study is the listed companies in the Borsa Istanbul Services Index (XUHIZ). The final data set of the study consists of 196 firm-years data from 49 companies covering the 4-years period between 2016-2019. Accounting based performance indicator "ROA" as a firm profitability and market-based performance indicator "Tobin's $Q$ ratio" were used as dependent variables. Investment in marketing efforts was represented by marketing intensity (MTS) and marketing expenditures to total operating expenditures ratio (MTOE). The effects of marketing investments on firm profitability and firm value were investigated using six econometric models. Various control variables were added to the models.

Since panel data analysis was chosen as a method, various tests were performed on variables and models before proceeding with analysis. The time series of all variables were checked by testing whether they contain unit root or not. Moreover, VIF (Variance Inflation Factor) multicollinearity tests were performed on each of the six models. In this respect, the study provided assurance against the problem of high correlation between independent variables in the same model and against spurious regressions.

However, after these assumptions were met, panel data analysis was initiated. Unlike many other studies, the Honda test was used to select the panel data model in this study, and Honda test results clearly showed that 6 models could not be pooled. Then, the most suitable panel data analysis method was determined with the Hausman test, which was used in many studies in the econometrics literature.

According to the results of the research, it was determined that the ratio of marketing expenses to total sales (MTS), which is the first independent variable representing marketing investments, does not have a positive effect on Tobin's $Q$. While no significant relationship was found in Model 1, a significant but negative relationship was found in Model 3. 
On the other hand, MTOE, another independent variable, was found to have a statistically significant positive effect on Tobin's $Q$ in Model 2 and Model 3.

In the remaining three models, the accounting-based performance ratio is used as the ROA dependent variable. Similar to the first three models, there is no statistical evidence that MTS increases financial performance in any way. In the econometric model (Model 6) where MTOE, the other independent variable, is included with MTS, it has been found that it significantly affects profitability.

While the results found in Model 1 and Model 3 established with Tobin's Q are inconsistent with the results of Doğan and Mecek (2015), they support the results of Kundu et al. (2010) and Konak (2015). In the models established with ROA (Model 4 and Model 6) the findings are in the same direction as Serçek et al. (2018).

When the research findings are discussed as a whole, it can be concluded firstly that the increase in the ratio of investment in marketing efforts to sales does not have a positive effect on the market value or profitability of the company. In fact, this result should not be surprising, because marketing efforts may not have the same impact on profitability even if it is possible to reflect on sales in the short term.

Another important inference that can be drawn from the research is that the increase in the ratio of marketing expenses to total operational expenses positively affects both the profitability and the market value of the company. (Considering Model 3 and Model 6, where two independent variables are in the same model). This finding indicates that marketing investments should not be considered separate from other operational expenses (such as general administrative expenses) of the firm, companies that can control other operational expenses and increase their allocation to marketing expenses can achieve better financial performance. In this respect, the study reveals important results not only in the context of finance or marketing, but also in the field of management. In the light of these findings, it can be said that the study will make significant contributions to companies, stakeholders, and researchers.

The issue of whether firms' marketing efforts work has always been an important and interesting issue for researchers. Not only researchers, but companies themselves are eager to know and learn about this, and 
they spend billions of dollars each year just for it. Of course, they want the product and the advertisement to be liked by the customer, but it is even more important to get the investment in financial terms. From a financial perspective, it is hoped that the advertisements, the premiums to the sales personnel, the expenditures for the huge marketing buildings, in short, the marketing investments will increase the sales, profits and cash flow. However, research findings show that increasing the ratio of marketing investments to sales does not increase the financial performance of the firm in the short term. In this context, it is recommended for companies operating in the service sector to consider their marketing investments together with financial and managerial factors (including controlling other operational expenses).

Despite the fact that this study appears to be about the relationship between marketing and finance, it actually differs from other studies in the field in that it emphasizes the importance of management in public companies. Another feature of the study is that it uses panel data analysis. In this respect, it includes both time and cross-section dimensions, reduces the risk of extraordinary factors affecting the results of the study in a single year and minimizes biased results.

This research includes only Turkey that is the most important limitation. For future research, it is recommended to conduct studies that cover more countries and have a wider time dimension, following the methodology in this research.

\section{References}

Agbeja, O., Adelakun, O. J. and Akinyemi, D. (2015). Analysis of the effect of advertising on sales and profitability of company. International Journal of Novel Research in Marketing Management and Economics, 2(3), 81-90.

Al-Nimer, M. A., Qasem, M. F., Aladham, M. F. and Yousef, A. A. (2015). The impact of marketing strategy on profitability in medical jordanian corporations. International Business Research, 8(11), 61-67.

Baltagi, B. H., Song, S. H. and Koh, W. (2003). Testing panel data regression models with spatial error correlation. Journal of Econometrics, 117, 123-150. 
Bolton, R. N. (2004). Linking marketing to financial performance and firm value. Journal of Marketing, 68(4), 73-75.

Breusch, T. and Pagan, A. (1980). The lagrange multiplier test and its applications to model specification in econometrics. The Review of Economic Studies, 47(1), Econometrics Issue, 239-253.

Doğan, M. and Mecek, G. (2015). A research on the effects of marketing spending on firm value. Journal of Business Research-Türk, 7(2), 180194.

Fu, L., Singhal, R. and Parkash, M. (2016). Tobin's q ratio and firm performance. International Research Journal of Applied Finance, 7, 1-10.

Gupta, N. (2008). Advertisement and firms' performance: An empirical analysis (May 15, 2008). Available at SSRN: https://ssrn.com/abstract $=1405014$.

Han, B. H. and Manry, D. (2004). The value-relevance of RandD and advertising expenditures: Evidence from Korea. The International Journal of Accounting, 39, 155-173.

Hausman, J. (1978). Specification tests in econometrics. Econometrica, 46(6), 1251-1271.

Honda, Y. (1985). Testing the error components model with non-normal disturbances. The Review of Economic Studies, 52(4), 681-690.

Konak, F. (2015). The effects of marketing expenses on firm performance: empirical evidence from the BIST Textile, Leather Index. Journal of Economics, Business and Management, 3(11), 1068-1071.

Kotler, P. (1997). Marketing management analysis, planning, implementation, and control. 9th Edition. Prentice Hall: Upper Saddle River.

Kundu, A., Kulkarni, P. and Murthy, A. N. K. (2010). Advertising and firm value: Mapping the relationship between advertising, profitability and business strategy in India (May 8, 2008). Changing Ideas in Strategy, Arun Sinha, ed., Narosa Publications, Available at SSRN: https://ssrn.com/abstract=1750792 Accessed on: 13.05.2020.

Levin, A., Lin, C.-F. and Chu, C.-S. J. (2002). Unit root tests in panel data: Asymptotic and finite-sample properties. Journal of Econometrics, 108(1), 1-24.

Madden, T. J., Fehle, F. and Fournier, S. (2006). Brands matter: An empirical demonstration of the creation of shareholder value through branding. Journal of the Academy Marketing Science, 34(2), 224-235. 
Mcclure, B. (2020). How to use ROA to judge a company's financial performance. Retrieved from https://www.investopedia.com/articles/fundamental/04/012804.asp. Accessed on: 14.06.2020.

Menard, S. (2011). Applied logistic regression analysis. 2nd edition. UK: SAGE Publications, Inc.

Öztürk, E. and Dülgeroğlu, İ. (2016). Pazarlama ve genel yönetim giderlerinin firma performansı üzerindeki etkisi. Niğde Üniversitesi İktisadi ve İdari Bilimler Fakültesi Dergisi, 9(3), 137-146.

Qureshi, M. I. (2007). Asset value of UK firms advertising expenditures. Global Journal of International Business Research (GJIBR), 1(1), 12-23.

Serçek, S., Kaya, S. B. and Kalash, I. (2018). pazarlama giderlerinin firma karlılığı üzerindeki etkisi: Bist turizm sektörü üzerinde bir araştırma., International Social Sciences Studies Journal, 4(23), 4370-4380.

Sheth, J. N. and Sisodia, R. S. (2002). Marketing productivity: Issues and analysis. Journal of Business Research, 55(5), 349-362.

Slywotzky, A. J. and Shapiro, B. (1993). Leveraging to beat the odds: The new marketing mind-set. Harvard Business Review, 71(5), 97-107.

Tatoğlu, F. Y. (2016). Panel veri ekonometrisi. 3rd edition. İstanbul: Beta Basım.

Topuz, Y. V. and Akşit N. (2013). İşletmelerin pazarlama giderlerinin hisse senetleri getirileri üzerindeki etkisi: İMKB gida sektörü örneğ., Anadolu Üniversitesi Sosyal Bilimler Dergisi, 13(1), 53-60.

\section{Citation Information}

Garbiah, M. TA. and Levent, C. E. (2021). Does investing in marketing efforts affect firm value and profitability? An application with panel data analysis. OPUS- Journal of International Society Studies, 18(44), 7539-7551. DOI: 10.26466/opus.894186. 